\title{
Terminologie vir Drywingselektronika (Deel IV) Tiristorterminologie (vervolg)
}

\author{
C.G. Steyn en J.D. van Wyk
}

Fakulteit Ingenieurswese, R.A.U., Posbus 524, Johannesburg 2000

\section{Tiristor vs. beheerde silikongelykrigter}

Gedurende die vroeë tiristortydperk is die naam $S C R$ - vir silicon controlled rectifier - deur veral die Amerikaanse verskaffers van drywingskomponente geskep en die wêreld ingestuur. Die gevolg hiervan was dat vertalingsinstansies in Suid-Afrika eenvoudig 'n regstreekse vertaling uit Engels in Afrikaans gemaak het en die benaming BSG - vir beheerde silikongelykrigter - het noodwendig gevolg.

Die benaming $S C R$ is waarskynlik aanvaar omdat daar op daardie stadium slegs 'n ,,onbeheerde' halfgeleierdrywingskakelelement - die diode - bestaan het; dit is in baie gevalle in silikontegnologie vervaardig. Omdat die (toe) nuwe vierlaaghalfgeleierelement ook in silikon vervaardig is, en boonop 'n beheerklem - die hek - gehad het, is die naam SCR toe ongelukkig in sommige lande gestandaardiseer.

Ons sê ,,ongelukkig"' want daar kan heelwat besware teen die benaming $S C R$ of BSG ingebring word:

(i) Die halfgeleiermateriaal waaruit hierdie element vervaardig word, hoef nie noodwendig silikon te wees nie.

(ii) Die element is méér as net 'n beheerde gelykrigter; dit is 'n aktiewe ontsteekbare bistabiele elektroniese skakelelement.

(iii) Die benaming $S C R$ is aanvanklik vir 'n spesifieke element (sperrende triodetiristor) bedoel, terwyl die benaming tiristor as genusnaam gebruik is. Algaande is $S C R$ egter as genusnaam gebruik, want van die elemente wat later ontwikkel is, is byvoorbeeld:

ASCR: asymmetrical silicon controlled rectifier;

LASCR: light-activated silicon controlled rectifier;

GATASCR: gate assisted turn-off asymmetrical silicon controlled rectifier.

(iv) Die vakuumekwivalent van die $S C R$ - die tiratron - het reeds lankal bestaan en die halfgeleierelement se benaming behoort dus hiermee verband te hou, mits die tiratron fundamenteel korrek benaam is.

Om egter 'n taalkundige, tegniese, bruikbare en verantwoorde benaming te vind, moet daar eerstens na die fundamentele gemeenskaplike eienskap gekyk word. Hierdie (gewoonlik) vierlaaghalfgeleierelemente het almal twee stabiele toestande - aan en af. Wat die eksterne stroombaan, waarin so 'n element verbind is, betref, tree die element soos 'n skakelaar op.
Die genusnaam moet dus op hierdie aan/af- (of toe/oop-) werking dui. Wat die tiratron betref sien ons dat die Griekse woord $\theta u ́ g \alpha$ (thura of thyra) deur of poort beteken, wat oop of toe (gesluit) kan wees. Dit lyk dus sinvol dat die stamvorm tira behou moet word. Die aan/afwerking van hierdie elemente kan ook beskou word as 'n element waar die elektriese weerstand of hoog (af-toestand) of laag (aantoestand) kan wees. Dit is dus ook van pas dat die vorm weerstand in die een of ander vorm betrek moet word. Die benaming tiristor, uit die samevoeging van thura en resisto, (Latynse woord vir ,,weerstand bied"), blyk aan al die gevraagde vereistes te voldoen, insluitend aanvaarbaarheid deur die spreker tiristor sê baie makliker as beheerde silikongelykrigter. Die meeste Europeërs het inderdaad nog altyd die term tiristor gebruik en daar is orals in die wêreld 'n al hoe groter ommeswaai na die term tiristor. Ons beveel ten sterkte aan dat die benaming beheerde silikongelykrigter (BSG) as verouderd beskou moet word en dat die term tiristor uitsluitlik gebruik word.

Indien tiristor as genusnaam gebruik, en daar met beheerde silikongelykrigter weggedoen word, kan daar tereg gevra word wat die benaming van die , ,oorspronklike" BSG moet wees. Die bestaande alternatiewe benaming sperrende triodetiristor is natuurlik korrek, maar weens die lang benaming nie baie gewild onder gebruikers nie. Omdat dit tans nog die algemeenste element in die tiristorfamilie is, lyk sperrende tiristor of sperrende tiristortriode ook toepaslik. Hierdie benaming kan egter verwarrend wees, want dit kan dui op enige tiristor wat in die spertoestand verkeer. In die praktyk het die deurbreekspanning (maksimum sperspanning) en die wipspanning (maksimum blokkeerspanning) dikwels numeries dieselfde waarde (d.w.s. 'n simmetriese kenkromme), a.g.v. die byna simmetriese dotering van 'die middelste twee PN-vlakke. Die benaming simmetriese tiristor of simmetriese tiristortriode of simmetriese triodetiristor lyk dus aanvaarbaar.

By die benaming van hierdie familie elemente is dit verkiesliker om bykomende beskrywende bepalings eerder by die skaars, as by die algemene elemente te hê. So kan 'n simmetriese tiristortriode kortweg 'n simmetriese tiristor, met afkorting SIMT (bv.), genoem word, terwyl 'n simmetriese tiristordiode (tweeklemtiristor) op die genoemde wyse beskryf moet word. Weens praktiese oorwegings sal daar noodwendig alternatiewe benaminge voorkom, soos 
bilaterale of tweerigtingsnellerdiode naas simmetriese snellerdiode of simmetriese tiristordiode.

Die algemene reël dat as daar geen verwarring kan ontstaan nie, die algemene of genusnaam vir 'n spesifieke element gebruik kan word, geld natuurlik steeds. By 'n stroombaan waar byvoorbeeld net simmetriese tiristors voorkom, kan daar gerus na die elemente as tiristors verwys word. 